\title{
Perkembangan Kreativitas Anak Melalui Permainan Pasir Ajaib di Taman Kanak-kanak
}

\author{
Kuntum Khairah Umah ${ }^{1}$, Rakimahwati ${ }^{2}$ \\ Pendidikan Anak Usia Dini, Universitas Negeri Padang, Indonesia \\ DOI: 10.31004/aulad.v4i1.8ㅌ
}

Corresponding author:

[kuntumkhairahumah@gmail.com]

Article Info Abstrak

Kata kunci:

Kreativitas;

Anak;

Permainan pasir ajaib

\begin{abstract}
Pentingnya pengembangan kreativitas anak sejak dini tidak hanya menjadikan anak lebih percaya diri dan kreatif tetapi juga terbiasa menggagas pikirannya dan kreatif dalam membuat suatu karya. Pemanfaatan pasir ajaib dapat menjadi inovasi permainan untuk mengembangkan kreativitas anak yang dapat digunakan dalam kegiatan menggambar dan membentuk. Tujuan penelitian ini ialah untuk mendeskripsikan perkembangan kreativitas anak melalui permainan pasir ajaib di Taman Kanak-kanak. Jenis penelitian menggunakan studi literatur dengan mengumpulkan data melalui berbagai bahan bacaan buku, artikel, dan hasil penelitian yang berhubungan dengan kajian penelitian yang kemudian dianalisis. Teknik analisis data menggunakan metode analisis isi bertujuan untuk menguraikan dan menyimpulkan isi dari sumber data. Hasil penelitian ini didasarkan atas temuan analisis permainan pasir ajaib bahwa permainan pasir ajaib dapat meningkatkan imajinasi anak, dapat menuangkan beberapa ide yang ada di pikiran anak, melatih kepercayaan diri anak, menstimulasi perkembangan anak, menstimulasi kreativitas anak dalam membentuk suatu karya baru, dan aman digunakan anak dalam bermain.
\end{abstract}




\section{PENDAHULUAN}

Pendidikan Anak Usia Dini (PAUD) merupakan sesuatu upaya pendidikan yang diperuntukan bagi anak dari lahir hingga umur 6 tahun untuk menolong perkembangan serta pertumbuhan anak secara optimal supaya bisa mempunyai kesiapan untuk merambah pendidikan lebih lanjut. Bagi (Suyadi dan Ulfah, 2015), PAUD juga merupakan pendidikan yang dilaksanakan untuk memfasilitasi pertumbuhan dan perkembangan anak secara menyeluruh pada pengembangan seluruh aspek karakter anak. Taman kanak-kanak (TK) merupakan salah satu wujud satuan pendidikan untuk anak usia dini (AUD) pada jalur pendidikan resmi yang menyelenggarakan program pendidikan anak usia 4 hingga 6 tahun (Sujiono, 2013). TK memegang peranan penting dalam proses mengembangkan aspek perkembangan dan kepribadian anak serta mempersiapkan anak menuju pendidikan lebih lanjut. Aspek yang harus dikembangkan di Taman Kanak-kanak meliputi nilai agama moral, kognitif, fisik motorik, sosial emosional, seni dan bahasa.

Salah satu perkembangan yang mesti dikembangkan ialah kreativitas. Kreativitas pada anak tidak sama dengan kreativitas orang dewasa. Kreativitas berarti memiliki kualitas ataupun kekuatan untuk mengekspresikan dengan cara anak sendiri tanpa bantuan orang lain (Nurani dkk., 2020). Kemampuan yang dimiliki individu untuk menghasilkan sebuah karya, baik berbentuk gagasan maupun produk baaru disebut dengan kreativitas. (Rachmawati dan Kurniati, 2019) mengatakan kreativitas ialah suatu proses yang menghasilkan ide, metode, proses, gagasan, produk baru yang bersifat flesibel, imajinatif, dan berguna. Kreativitas dimaknai sebagai upaya mengembangkan cara lama yang sudah dianggap tidak efektif lagi dan menemukan cara baru agar lebih efektif dan efisien (Susanto, 2017). Kreativitas menjadikan anak lebih aktif dalam setiap kegiatan. Karena membebaskan anak untuk mengeksplor semua ide dan gagasan yang ada dipikirannya tanpa ada campur tangan dari orang lain. Pendidik harus mengetahui potensi dan kemampuan kreativitas yang dimiliki oleh setiap anak didiknya serta perlu mendorong dan mengembangkan kreativitas alami yang sudah dimiliki anak agar dapat berkembang secara optimal.

Dunia imajinasi atau khayal adalah dunia yang identik dengan anak, dengan imajinasi anak dapat membuat sesuatu yang baru dan bisa menemukan solusi dari masalah yang dihadapi dalam mengembangkan kreativitas pada anak (Rachmawati dan Kurniati, 2019). Menurut Masganti dkk., (2016) dunia anak ialah dunia kreativitas, yang berarti anak memerlukan ruang gerak, berpikir serta emosional yang terbimbing. Kemampuan berpikir ialah satu dari beberapa aspek yang mempengaruhi timbulnya kreativitas anak, sedangkan kecerdasan emosi atau perasaan merupakan aspek yang berhubungan dengan kesabaran dalam menghadapi bermacam permasalahan yang berkaitan dengan kreativitas. Kreativitas mengaitkan interaksi antara perasaan, otak serta gerak pada kegiatan yang sangat mengasyikkan ialah aktivitas bermain. Sejalan dengan pendapat Hurlock (1978) terdapat hubungan positif antara kreativitas dengan kecerdasan. Kreativitas tidak dapat berkembang jika tidak ada pengetahuan, karena kreativitas membutuhkan dan menggunakan pengetahuan yang diterima sebelumnya dan bergantung pada kemampuan intelektual seseorang. Kreativitas pada AUD lebih mengarah pada keaktifan anak dalam bermain, karena pada hakikatnya dunia anak itu bermain. Hal kreatif pada anak bisa dilihat saat anak bermain, anak mampu memilih, mengklasifikasikan, menyusun, menata, memisahkan, meniru, berinteraksi dengan teman, dan melakukan koordinasi gerakan bahkan sampai anak dapat memecahkan masalah (Khamaliyah dkk., 2019).

Kreativitas anak di umur 8-10 tahun dari berbagai negara, termasuk Indonesia menempati posisi terendah kreativitas anak-anak dibanding dari 8 negara yang lain. Indonesia menduduki jauh di bawah Fhilipina, Amerika Serikat, Jerman, Inggris, India, Kamerun, RRC, serta Zulu. Diperkirakan banyak aspek yang jadi pemicu rendahnya kreativitas anak di Indonesia. Sebagian aspek tersebut antara lain merupakan pola asuh orang tua yang cenderung menggunakan pola asuh otoriter dan sistem pendidikan. Selain itu faktor dari diri sendiri juga dapat menghambat pengembangan kreativitas seperti psikologis, fisiologis, biologis, dan sosiologis (Rachmawati dan Kurniati, 2019). Menurut hasil survei nasional pendidikan di Indonesia menunjukkan bahwa sistem pendidikan formal di Indonesia masih kurang memberikan kesempatan pada anak dalam mengembangkan kreativitasnya. Pernyataan tersebut menunjukkan bahwa pengembangan kreativitas pada anak usia dini belum dikembangkan dengan optimal, oleh sebab itu potensi dan kreativitas anak perlu dikembangkan sejak dini melalui upaya pendidikan, baik di lingkungan sekolah, rumah dan masyarakat (Khamaliyah dkk., 2019).

Pentingnya pengembangkan kreativitas sejak dini tidak hanya menjadikan anak lebih percaya diri dan kreatif, tetapi juga terbiasa menggagas pikirannya dan kreatif dalam membuat suatu karya. Menurut Munandar dalam (Rachmawati dan Kurniati, 2019) perlunya pengembangan kreativitas sejak dini sebab melalui kreasi, anak dapat mewujudkan dirinya, dan sebagai kebutuhan pokok manusia, kreativitas selaku kemampuan untuk menciptakan cara- cara dalam pemecahan masalah, menyibukan diri secara kreatif tidak hanya berguna untuk diri sendiri serta lingkungan namun juga membagikan kepuasan seseorang, dan kreativitas membolehkan manusia untuk tingkatkan mutu hidup. Kegiatan pengembangan kreativitas anak terdiri atas kegiatan seni gambar atau corak, seni bentuk, seni tari, seni musik serta seni suara. Misalnya kegiatan dengan memakai kertas, krayon, pensil warna, bahan alam, pasir, bahan bekas, tanah liat, dan sebagainya. Dalam mengembangkan seni bentuk anak dapat menggunakan permainan playdough, kolase, meronce, melipat kertas, bermain pasir buatan, membuat stempel dan membuat suatu bentuk dari batang korek api (Wulandari, 2018). 
Mengembangkan kreativitas AUD dapat dilakukan dengan cara bermain sembari belajar, belajar sekaligus bermain. Bermain ialah kegiatan yang menyenangkan, dengan bermain anak dapat membangun pengalaman, kreativitas dan rasa ingin tahu anak (Nurani dkk., 2020). Menurut Sujiono (2013) permainan dapat membebaskan anak dalam menggali potensi diri, berimajinasi, serta berkreativitas. Bermain dan permainan memiliki arti penting bagi perkembangan anak. Salah satu permainan yang bisa mengembangkan kreativitas anak ialah pasir ajaib. Permainan ajaib ini dapat dilakukan dengan kegiatan menggambar dan membentuk. Menggambar menggunakan pasir ajaib bisa mengembangkan ide serta gagasan dalam kegiatan menggambar dan menceritakan hasil gambar sejalan dengan imajinasi anak. Kegiatan membentuk dapat mengembangkan ide dan perasaan anak sesuai imajinasi anak dalam membuat berbagai macam bentuk.

Penelitian ini didukung penelitian terdahulu yang dilakukan Takahopekang dkk., (2020) mengenai kreativitas anak usia dini melalui metode bermain pasir ajaib dengan menggunakan metode quasi eksperimen. Berdasarkan hasil penelitian menyatakan bahwa kreativitas anak akan lebih berkembang dengan ide yang baru yaitu pasir ajaib. Kemampuan anak kelompok eksperimen menggunakan pasir ajaib lebih baik dibandingkan kelompok kontrol tidak menggunakan pasir ajaib. Hal tersebut dikarenakan pada saat pembelajaran menggunakan pasir ajaib, anak bisa menuangkan ide-ide yang ada dalam pikiranya melalui permainan pasir ajaib, anak bisa melalukan praktek meniru huruf di atas pasir ajaib serta dengan percaya diri menyebutkan nama dan manfaat dari kegiatan yang dilakukan anak. Selanjutnya penelitian yang dilakukan Dunggio (2019) mengenai meningkatkan kemampuan motorik halus dan kreativitas anak dengan menggunakan pendekatan saintifik melalui media pasir ajaib pada anak di Kabupaten Pohuwato. Penelitian ini menggunakan penelitian tindakan kelas yang dilaksanakan dengan dua siklus yang semakin meningkat pada siklus kedua, hasil yang diperoleh pada siklus kedua memiliki kemandirian yang tinggi $75 \%$, memiliki imajinasi tersendiri $15 \%$, konsentrasi yang kuat $10 \%$. Hasil penelitian ini menunjukkan bahwa dengan menggunakan pendekatan saintifik melalui media pasir ajaib dapat meningkatkan kemampuan motorik halus dan kreativitas anak di kelompok B di TK Tunas Harapan Kecamatan Popayato Timur Kabupaten Pohuwato.

Pasir ajaib merupakan campuran pasir berbahan sintesis yang kemudian menghasilkan pasir dengan permukaan yang lebih halus dari pasir pantai, cuma menempel pada pasir ajaib itu sendiri dan tidak berantakan. Pasir ajaib dapat digunakan anak dalam bermain, seperti membuat istana, patung, bermacam bentuk buah atau binatang (Annisa dkk., 2018). Bermain pasir ajaib pada anak adalah kegiatan yang sangat mengasyikkan. Karena tidak hanya mendapatkan rasa senang, namun juga dapat mengembangkan kemampuan sensorik, motorik halus anak, kemampuan berpikir, perkembangan otak, kreativitas, imajinasi, mengenal warna dan bentuk (Wulandari, 2018).

Pasir ajaib tidak sama seperti pasir biasanya karena memiliki permukaan hidrofobik yang menolak air agar tidak basah. Pasir ajaib akan menggumpal saat dimasukkan ke dalam air dan tidak terlihat seperti pasir biasanya. Saat pasir diambil dari air, pasir ajaib tersebut tetap dalam keadaan kering serta masih menderas saat dijatuhkan (Peleg dkk., 2015). Pasir ajaib ini juga memiliki permukaan yang lebih halus dari pasir biasanya serta hanya menempel pada pasir ajaib itu sendiri sehingga mudah dibentuk anak sesuai imajinasinya dalam kegiatan membentuk dan menggambar. Banyak manfaat didapat dari permainan pasir ajaib diantaranya melatih kemampuan motorik halus anak, melatih kemampuan imajinasi serta kreativitas anak dari bermacam warna dan bentuk cetakan pasir, melatih kemampuan bekerjasama, dan kemampuan kognitif anak (Umami dkk., 2020).

Pemanfaatan pasir ajaib ini dapat menjadi inovasi permainan untuk mengembangkan kreativitas anak. Anak dapat menggunakan pasir ajaib ini melalui bermain. Bermain ialah suatu kegiatan yang mengasyikkan dan spontan bagi anak. Bermain bisa dapat memberi kesempatan kepada anak untuk mengembangkan kreativitasnya. Melalui pasir ajaib ini anak dapat menggambar dengan menggunakan berbagai macam warna pasir ajaib, membuat istana, membuat berbagai macam bentuk binatang, dan buah sesuai imajinasinya. Selain mudah dibentuk, aman, tidak berantakan, bersih, memiliki bermacam warna yang menarik, menyenangkan, dan bisa mengembangkan kreativitas dan imajinasi anak, pasir ajaib ini juga bisa melatih motorik halus anak, mengembangkan sosial emosional, kemampuan berpikir, mengenal bentuk dan warna.

Penelitian ini diharapkan dapat bermanfaat dalam memberikan konstribusi ilmu pengetahuan yang berkenaan dengan perkembangan kreativitas anak melalui permainan pasir ajaib di Taman Kanak-kanak. Manfaat untuk kepala sekolah menjadi bahan pertimbangan untuk pembinaan kepada guru, manfaat untuk guru memberikan masukan kepada guru tentang bagaimana perkembangan kreativitas anak melalui permainan pasir ajaib di Taman Kanak-kanak, manfaat untuk anak meningkatkan kreativitas anak, membantu mengoptimalkan potensi anak serta menumbuhkan rasa percaya diri anak dalam berkreativitas. Manfaat untuk peneliti memberikan informasi dan acuan tentang perkembangan kreativitas anak melalui permainan pasir ajaib, serta menjadi bahan masukan untuk penelitian selanjutnya yang akan meneliti dan membahas lebih lanjut tentang perkembangan kreativitas anak melalui permainan pasir ajaib di Taman Kanak-kanak.

\section{METODOLOGI}

Jenis penelitian ini menggunakan studi literatur. Karakteristik penelitian kepustakaan termasuk ke dalam metode penelitian kualitatif, oleh karena itu ciri-ciri penelitian kualitatif diubah dalam konteks penelitian kepustakaan. Mengubah kegiatan observasi dan wawancara menjadi analisis teks dan wacana. Mengganti setting 
lapangan ke ruang perpustakaan (Hamzah, 2020). Dalam konteks penelitian kepustakaan, informasi, dan data diambil dari bahan-bahan pustaka, kemudian dianalisis berdasar pada kerangka berpikir yang melandasinya dan menggunakan pendekatan sesuai dengan tujuan penelitian. Alasan menggunakan penelitian kepustakaan yaitu dengan memanfaatkan bahan-bahan pustaka pada masa pandemi Covid-19 ini untuk memperoleh data penelitian sehingga tidak memerlukan penelitian lapangan dan hanya membatasi pada kegiatan bahan-bahan pustaka dan internet. Langkah-langkah dalam penelitian kepustakaan yaitu (Ramdhani dkk., 2014): 1) memilih topik sesuai kajian penelitian; 2) mencari dan memilih artikel yang sesuai; 3) menganalisis dan menyintesis literatur; 4) mengorganisasi penulisan kajian.

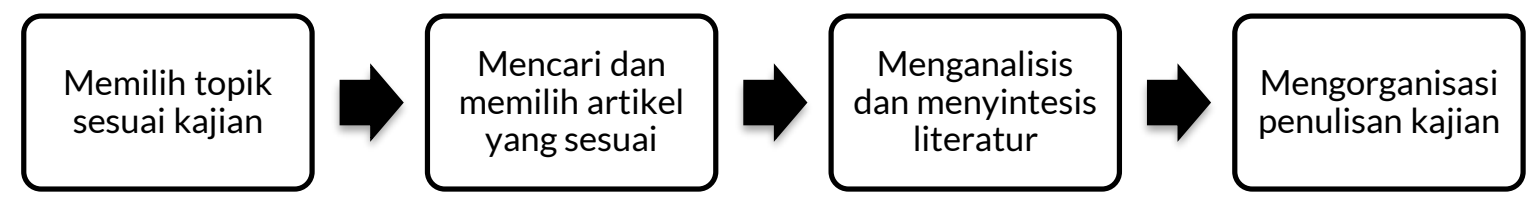

Gambar 1. Langkah-langkah Penelitian Kepustakaan

Sumber data yang dipakai yakni data yang didapat dari artikel yang terdapat pada jurnal, buku referensi, dan hasil penelitian mengenai kreativitas anak dan pasir ajaib. Jumlah artikel yang dianalisis sebanyak 25 artikel, range waktu terbit artikel 2010-2020 dan buku referensi sebanyak 9 buku, range waktu terbit buku mulai tahun 19782020. Menurut Hamzah (2020) langkah-langkah pengumpulan data dalam penelitian kepustakaan yaitu: 1) mengumpulkan literatur yang berkaitan dengan topik penelitian seperti dari artikel yang terdapat pada jurnal, buku referensi, dan hasil penelitian; 2) mengelompokkan berbagai buku, dokumen, atau sumber data lainnya berdasar pada tingkatan kepentingan sumber primer, sekunder, dan tersier; 3) mengutip berbagai data yang dibutuhkan sejalan dengan topik penelitian lengkap dengan sumbernya; 4) mengonfirmasi atau memeriksa kembali data dari sumber utama dan sumber lain untuk kepentingan validitas; 5) mengelompokkan data berdasarkan sistematika laporan.

Teknik analisis data memakai metode analisis isi. Bagi Mirzaqon (2018) teknik analisis data penelitian kepustakaan dapat dengan memakai metode analisis isi. Proses analisis isi dilakukan dengan memilah, menyamakan, mencampurkan, serta memisahkan bermacam penafsiran sampai ditemukan yang relevan. Analisis data dapat dilakukan saat pengumpulan data dan sesudah selesai pengumpulan data. Tujuan metode analisis isi adalah untuk menguraikan dan menyimpulkan isi dari sumber data (Hamzah, 2020). Setelah mengumpulkan dan mendapatkan data yang sesuai dengan kajian penelitian kemudian data dianalisis menggunakan metode analisis isi. Analisis data dikaitkan dengan konsep dan teori yang relevan. Tujuan analisis data adalah untuk mendeskripsikan perkembangan kreativitas anak melalui permainan pasir ajaib di Taman Kanak-kanak. Analisis ini dilakukan untuk memperoleh kesimpulan yang valid serta bisa diteliti ulang sesuai konteksnya.

\section{HASIL DAN PEMBAHASAN}

Kreativitas ialah salah satu kemampuan yang dipunyai anak yang butuh dibesarkan semenjak usia dini, karena tiap anak mempunyai potensi kreatif. Potensi kreativitas anak dapat dilihat dari anak yang suka mengeksplorasi segala sesuatu yang ada disekitarnya. Hal ini dapat diketahui dari prilaku anak yang suka bertanya, suka memerhatikan hal baru, suka mencoba hal yang baru, suka berimajinasi, dan suka membuat sesuatu melalui benda apa saja yang ada disekitarnya (Rachmawati dan Kurniati, 2019). Menurut Hurlock (1978) kreativitas memberikan rasa senang dan kepuasan sendiri pada anak yang sangat besar pengaruhnya terhadap perkembangan kepribadiannya. Menurut Yildirim (2010) mendukung kreativitas dalam proses pendidikan memiliki arti yang sangat penting dalam setiap tahap pendidikan formal. Dalam hal ini, mengembangkan kreativitas anak sejak usia usia dini sangat penting.

Salah satu hal yang menjadi prinsip pada PAUD ialah untuk mendorong timbulnya kreativitas, inovatif, serta meningkatkan kecakapan hidup anak. Dorongan yang diberikan bersifat merata serta mencakup seluruh aspek perkembangan anak. Hal utama dalam proses pendidikan merupakan bakat kreatif anak bisa dikembangkan dan ditingkatkan. Mengembangkan kreativitas anak dapat dilakukan dengan bermain drama, bermain pasir, bermain boneka, kertas lipat, bermain musik, bermain sambung cerita, dan meniru bentuk (Susanto, 2017). Bermain pasir ajaib dapat dilakukan dengan kegiatan menggambar dan membentuk. Menggambar dan membentuk menggunakan pasir ajaib dapat mengembangkan ide dan gagasan yang ada dalam pikiran anak, dan menceritakan hasil gambarnya sesuai imajinasi anak.

Kreativitas anak berbeda dengan kreativitas orang dewasa. Kreativitas anak didasari oleh keunikan gagasan, tumbuhnya imajinasi dan fantasi. Anak kreatif lebih condong memperoleh rangsangan dan kebebasan dalam beraktifitas. Stimulasi dapat diberikan dengan memberi kebebasan pada anak untuk melakukan, membentuk, memegang, menggambar, atau membuat sesuatu dengan caranya sendiri dan membebaskan anak untuk menuangkan imajinasinya. Kala anak meningkatkan keterampilan kreatifnya hingga anak juga bisa menciptakan ideide yang inovatif serta dapat memecahkan masalahnya sendiri (Maulana dan Mayar, 2019). 
Perlunya pengalaman yang bermakna untuk mengembangkan kemampuan berpikir imajinatif anak. Pengalaman yang diperoleh anak bukan hanya saja dari campur tangan orang tua dan guru, tetapi juga lebih memberikan kesempatan kepada untuk melakukannya sendiri dengan potensi yang dimilikinya. Peran guru dan orang tua dalam hal ini ialah memberikan stimulasi yang tepat agar mendapatkan pengalaman yang bermakna dalam mengembangkan kreativitasnya (Lestari, 2020). AUD berperilaku dan berpikir kreatif apabila anak tersebut berada dalam lingkungan yang sengaja didesain untuk mendorong munculnya perilaku kreatif pada anak (Nurani dkk., 2020).

Menurut (Nurani dkk., 2020) menjelaskan indikator kreativitas AUD yaitu: 1) kelancaran adalah anak memiliki selera humor yang tinggi dan mengekspresikan imajinasi secara verbal; 2) kelenturan adalah anak yang mau mengambil resiko, mencoba hal yang baru dan menantang, serta suka menggunakan imajinasinya dalam bermain; 3 ) keaslian adalah anak melakukan sesuatu dengan caranya sendiri dan menjadi inovatif; 4) elaborasi adalah anak yang termotivasi dan terarah sendiri, senang berimajinasi, suka berfantasi dan terlibat dalam eksplorasi; 5) keuletan dan kesabaran adalah anak yang berpendirian tegas, mau berbicara secara terbuka, dan terang-terangan.

Menurut Hurlock (1978) menyatakan bahwa menjadi kreatif memiliki arti penting bagi anak, karena dapat menambah ilmu pada permainannya. Jika kreativitas bisa menjadikan permainan lebih menyenangkan maka anak akan merasa senang, puas, dapat mengembangkan kepribadian dan sosial anak. Semakin bertambahya usia anak, maka prestasi termasuk dalam kepentingan utama pada penyesuaian hidup anak. Kreativitas dapat membantu anak memeroleh keberhasilan dibidang yang berarti baginya. Sehingga dapat ditarik kesimpulan bahwa kreativitas berperan sangat penting untuk perkembangan anak. Apabila kreativitas anak berkembang sesuai dengan indikator yang telah diuraikan, maka akan berpengaruh terhadap aspek-aspek perkembangan anak lainnya.

Meningkatkan kreativitas AUD dicoba dengan cara bermain sembari belajar, belajar sambil bermain. Bermain membagikan peluang kepada anak untuk meningkatkan kreativitasnya, karena dengan bermain anak bisa melalukan percobaan dengan gagasan barunya dan mengekspresikan dorongan kreatifnya baik menggunakan alat permainan maupun tidak memakai alat permainan. Kala anak merasa dapat menghasilkan suatu yang unik serta baru, maka anak akan mencoba dan melakukannya sendiri (Fakhriyani, 2016). Permainan merupakan sesuatu media yang mengasyikkan serta memuaskan untuk anak buat menekuni sesuatu, dengan bermain anak belajar sesuatu tanpa disadarinya tetapi senantiasa diingat sebab sifatnya yang mengasyikkan serta membantu mencapai perkembangan anak yang optimal (Kurniawan dkk., 2020).

Permainan memberi kebebasan kepada anak buat berimajinasi, menggali kemampuan diri, serta berkreativitas. Bermain dan permainan memiliki arti penting bagi perkembangan anak karena mendapatkan pengalaman langsung (Sujiono, 2013). Permainan merupakan metode utama yang digunakan di seluruh pendidikan anak usia dini, karena merupakan cara pembentukan kepribadian anak. Melalui permainan anak dapat bereksperimen, bereksplorasi, menemukan, dan mengenal lingkungan sekitarnya dengan cara yang alami (Lucas, 2017). Salah satu permainan yang bisa mengembangkan kreativitas anak ialah pasir ajaib. Pasir ajaib adalah mainan yang hampir sama dengan pasir tetapi memiliki permukaan yang lebih halus (Wulandari dkk, 2020). Menurut Jatmika dalam (Wulandari, 2018) bermain pasir ajaib memberikan kebebasan kepada anak untuk menuangkan kreativitasnya dan memberikan waktu istirahat bagi anak dalam menggunakan alat tulis disekolah. Sejalan dengan pendapat (Umami dkk., 2020) banyak manfaat yang didapat dari permainan pasir ajaib diantaranya ialah melatih kemampuan motorik halus anak, melatih kemampuan imajinasi serta kreativitas anak dari bermacam warna dan wujud cetakan pasir, melatih kemampuan bekerjasama, dan kemampuan kognitif anak.

Pasir kinetik atau kerap diucap dengan pasir ajaib adalah perpaduan pasir dengan bahan sintesis yang menciptakan pasir dengan permukaan yang halus dari pasir biasanya, tidak lengket di tangan, cuma menempel sesama pasir itu sendiri dan tidak berantakan. Pasir ajaib ini dapat digunakan anak dalam bermain membuat istana, arca, bermacam wujud buah serta binatang (Annisa dkk., 2018). Pasir ajaib ini merupakan mainan yang termasuk masih baru dan belum semua sekolah menggunakan pasir ajaib ini (Mardiati dan Hartati, 2020). Bermain pasir ajaib ialah kegiatan yang menyenangkan bagi anak. Ekspresi anak dapat terlihat ketika anak berhasil menciptakan suatu bentuk. Bermain pasir ajaib ini tak hanya memberikan rasa senang kepada anak, tetapi juga bisa meningkatkan kemampuan sensorik, mengembangkan kreativitas, kemampuan berpikir, perkembangan otak, penyaluran imajinasi, mengenal warna dan bentuk (Wulandari, 2018).

Berdasarkan hasil penelitian (Takahopekang dkk., 2020) menyatakan kreativitas anak akan lebih berkembang dengan ide yang baru yaitu pasir ajaib. Kemampuan anak lebih baik menggunakan pasir ajaib dibandingkan tidak menggunakan pasir ajaib. Hal tersebut dikarenakan pada saat pembelajaran menggunakan pasir ajaib, anak bisa menuangkan ide-ide yang ada dalam pikiranya melalui permainan pasir ajaib, anak bisa melalukan praktek meniru huruf di atas pasir ajaib serta dengan percaya diri menyebutkan nama dan manfaat dari kegiatan yang dilakukan anak. Selanjutnya penelitian yang dilakukan Dunggio (2019) mengenai meningkatkan kemampuan motorik halus dan kreativitas anak dengan menggunakan pendekatan saintifik melalui media pasir ajaib pada anak di Kabupaten Pohuwato. Penelitian ini menggunakan penelitian tindakan kelas yang dilaksanakan dengan dua siklus yang semakin meningkat pada siklus kedua, hasil yang diperoleh pada siklus kedua memiliki kemandirian yang tinggi $75 \%$, memiliki imajinasi tersendiri 15\%, konsentrasi yang kuat $10 \%$. Hasil penelitian ini menunjukkan bahwa dengan menggunakan pendekatan saintifik melalui media pasir ajaib dapat meningkatkan kemampuan motorik halus dan kreativitas anak di kelompok B di TK Tunas Harapan Kecamatan Popayato Timur Kabupaten Pohuwato. 
Penelitian yang dilakukan (Khamaliyah dkk., 2019) mengenai pengaruh bermain pasir kinetik terhadap kreativitas anak menunjukkan bahwa terdapat pengaruh yang signifikan bermain pasir kinetik terhadap kreativitas anak. Kreativitas anak usia 5-6 tahun menggunakan pasir kinetik pada kelas eksperimen memperoleh skor rata-rata post test 47,43, sedangkan kreativitas anak usia 5-6 tahun menggunakan pembelajaran konvensional pada kelas kontrol memperoleh post test 41,43 hal ini menunjukkan bahwa kreativitas usia 5-6 tahun yang memperoleh pembelajaran menggunakan pasir kinetik lebih baik dari pada kreativitas anak usia 5-6 tahun yang memperoleh pembelajaran konvensional yang tidak menggunakan pasir kinetik. Selanjutnya penelitian (Wulandari, 2018) penggunaan permainan kinetic sand berpengaruh secara signifikan terhadap perkembangan kreativitas anak. Hal ini ditunjukkan dengan perbedaan perkembangan kreativitas yang signifikan antara kelompok kontrol dan kelompok eksprimen yaitu perkembangan kreativitas pada kelompok eksperimen lebih baik dari pada kelompok kontrol, dari nilai rata-rata dan taraf signifikasi yang dihasilkan. Perkembangan kreativitas anak sebelum dilakukan penelitian $53 \%$ kategori sedang dan $47 \%$ kategori rendah, dan setelah dilakukan penelitian meningkat menjadi $70 \%$ kategori tinggi dan $30 \%$ kategori sedang.

Bermain pasir kinetik memiliki potensi untuk mengembangkan kemampuan seni dan kreatif anak, kemampuan untuk melihat, memahami, dan menciptakan sesuatu. Awalnya anak belajar menggambar di atas pasir. Dalam pembelajaran anak disediakan tiga jenis contoh yaitu subjek, cerita, dan dekoratif. Cetakan subjek anak menggambar menggunakan cetakan dan mengumpulkannya dengan tangan, misalnya pohon dan batang kemudian daunnya dibentuk dengan tangan. Cetakan cerita melibatkan beberapa benda yang ada di kotak pasir sesuai dengan topik. Cetakan dekoratif dengan menghias objek menggunakan pola manik-manik, kancing, dan batu. Hal ini dapat mendorong kemampuan imajinasi dan kreatif anak (Andreeva dkk., 2018).

Berdasarkan dari berbagai artikel yang terdapat pada jurnal, buku, dan hasil penelitian yang sudah ada sebelumnya analisis perkembangan kreativitas anak melalui permainan pasir ajaib maka peneliti dapat menganalisis sebagai berikut:

Permainan pasir ajaib bisa meningkatkan imajinasi anak dalam mengembangkan kreativitas. AUD ialah anak yang gemar berimajinasi dan kaya akan imajinasi. Imajinasi ialah salah salah satu indikator kreativitas AUD. Sebagaimana penjelasan (Nurani dkk., 2020) indikator kreativitas anak usia dini yaitu kelancaran adalah anak mengekspresikan imajinasi secara verbal, kelenturan adalah anak suka menggunakan imajinasinya dalam bermain, dan elaborasi adalah anak senang berimajinasi dan menyukai fantasi. Sebagaimana pendapat (Khamaliyah dkk., 2019) manfaat pasir ajaib terhadap kemampuan belajar AUD yaitu merangsang kreativitas dan imajinasi anak dengan membuat berbagai bentuk, cerita, dan bermain peran menggunakan pasir ajaib. Hal ini sejalan dengan pendapat Jatmika dalam (Wulandari, 2018) bermain pasir ajaib memberikan kebebasan kepada anak untuk menuangkan kreativitasnya dan memberikan waktu istirahat bagi anak dalam menggunakan alat tulis sekolah. Selanjutnya hasil penelitian Dunggio (2019) memakai pendekatan saintifik melalui media pasir ajaib dengan pendekatan tindakan kelas yang telah dilaksanakan dapat meningkatkan kreativitas anak dengan memiliki kemandirian yang tinggi, memiliki imajinasi tersendiri, dan memiliki konsentrasi kuat yang mengalami peningkatan pada setiap siklus.

Permainan pasir ajaib bisa meningkatkan kreativitas AUD sebab anak bisa menuangkan ide-ide yang ada dalam pikirannya serta melatih kepercayaan diri anak. Sebagaimana hasil penelitian (Takahopekang dkk., 2020) kemampuan kreativias anak lebih baik menggunakan permainan pasir ajaib. Hal tersebut dikarenakan pada saat pembelajaran menggunakan pasir ajaib anak bisa menuangkan ide-ide yang ada dalam pikirannya melalui permainan pasir ajaib, anak bisa melakukan praktek dalam meniru huruf di atas pasir ajaib serta dengan percaya diri menyebutkan nama dan manfaat dari kegiatan yang dilakukan anak. Hal ini sejalan dengan pendapat (Andreeva dkk., 2018) bermain pasir kinetik memiliki potensi untuk mengembangkan kemampuan seni dan kreatif anak, kemampuan melihat, memahami, dan menciptakan sesuatu.

Pasir ajaib merupakan salah satu permainan yang bisa diterapkan sebagai aktivitas bermain sambil belajar untuk mengembangkan kreativitas anak. Permainan pasir ajaib ini sangat menyenangkan dan mudah dilakukan anak. Menurut Lucas (2017) anak belajar sambil bermain, permainan merupakan bagian dari perkembangannya dan menjadi cara belajar yang paling efektif untuk mengembangkan seluruh aspek perkembangan anak. Sebagaimana pendapat (Wulandari, 2018) bermain pasir ajaib merupakan bentuk aktivitas yang sangat menyenangkan bagi anak. Ekspresi anak dapat terlihat ketika anak berhasil menciptakan suatu bentuk. Sejalan dengan pendapat (Wahyuni dkk., 2017) bermain pasir dapat membantu mengembangkan imajinasi anak mengenai berbagai hal yang berada di luar lingkungannya sehingga perkembangan pemikiran serta kreativitas anak dapat berkembang dan tidak terbatas pada hal tertentu. Selanjutnya menurut (Oktariana dan Nufus, 2016) bermain pasir ajaib menjadi salah satu kegiatan yang disenangi dan disukai anak. Kegiatan bermain pasir selain bisa dijadikan sebagai sarana bermain, tetapi juga bisa dimanfaatkan untuk menstimulus kreativitas pada anak.

Permainan pasir ajaib dapat menstimulasi perkembangan anak. Stimulasi yang diberikan kepada anak sejak usia dini sangat berpengaruh pada tumbuh kembang anak. Oleh karena itu, upaya pendidikan yang bisa menstimulasi perkembangan anak termasuk kreativitas sangatlah dibutuhkan. Pendekatan Vygotsky mengatakan bahwa bermain ialah sebagai sumber utama perkembangan anak pada masa prasekolah yang memungkinkan anak usia dini untuk dapat memasuki pendidikan lebih lanjut (Blazhenkova dan Booth, 2020). Sebagaimana penjelasan (Khamaliyah dkk., 2019) manfaat pasir ajaib terhadap kemampuan belajar anak yaitu: 1) menstimulus sensori indra 
peraba, menyentuh, serta meremas pasir ajaib untuk merasakan permukaannya; 2) melatih motorik halus, membuat berbagai macam bentuk menggunakan tangan, melatih menggambar, dan pra menulis; 3) melatih konsentrasi dan membuat suatu bentuk; 4) merangsang kreativitas dan imajinasi, membuat berbagai bentuk, cerita, dan bermain peran menggunakan pasir ajaib; 5) melatih sosialisasi, bermain bersama teman dan belajar saling berbagi. Hal ini sejalan dengan pendapat (Nurhidayah, 2018) permainan pasir ajaib memilki manfaat terhadap perkembangan anak, diantaranya untuk mengembangkan kreativitas anak serta sebagai tempat berkumpul untuk sosialisasi bersama teman.

Permainan pasir ajaib dapat menstimulasi kreativitas anak dalam membentuk suatu karya yang baru dengan membuat berbagai macam bentuk menggunakan cetakan maupun tidak menggunakan cetakan. Menurut Yildirim (2010) anak secara tidak sadar memiliki kemampuan untuk menciptakan sesuatu. Anak mengekspresikan dirinya melalui imajinasi, emosi, kemampuan berpikir dan motivasi yang ada dalam dirinya. Menurut Piaget dalam (Asmah dan Mustaji, 2014), pasir ajaib merupakan mental complexity, yakni sebagai bahan dengan banyak kegunaan yang bisa bermanfaat bagi kegiatan bermain AUD, seperti bermain mengontruksi (membangun istana pasir) dan bermain drama (bermain membuat aneka bentuk kue). Sejalan dengan pendapat (Annisa dkk., 2018) pasir ajaib dapat digunakan anak dalam bermain membuat istana, patung, berbagai macam bentuk buah dan binatang. Selanjutnya menurut Hurlock (1978) menyatakan bahwa kreativitas memberikan rasa senang dan kepuasan sendiri pada anak yang sangat besar pengaruhnya terhadap perkembangan kepribadiannya. Sebagai contoh rasa puas yang dimiliki anak dari menciptakan sesuatu sendiri, seperti membuat bentuk istana, menggambar, dan membuat berbagai macam bentuk dari pasir ajaib.

Pasir ajaib memiliki permukaan yang lebih lembut, bersih, dan aman digunakan anak dalam bermain mengembangkan kreativitas. Menurut (Azeri dkk., 2015) salah satu cara untuk mengembangkan kreativitas anak yaitu dengan memanfaatkan pengaruh lingkungan alam atau buatan untuk meningkatkan kreativitas anak usia dini. Sebagaimana penjelasan (Hidayati, 2020) pasir ajaib terjamin kebersihannya sehingga aman digunakan dalam bermain, sifat pasirnya yang menempel satu sama lain mudah dibentuk anak sesuai keinginan, permukaan pasir ajaib lebih halus dan lembut dari pada pasir biasanya, pasir ajaib bisa digunakan sebagai media pembelajaran AUD, serta memiliki bermacam warna menarik yang disukai anak. Sejalan dengan pendapat (Muthiah dkk., 2020) pasir ajaib tak menempel pada benda lain selain sesama pasir itu sendiri serta tidak mengering, tetapi sebaliknya pasir ajaib ini meniru sifat fisik pasir basah. Memiliki permukaan yang lebih lembut dan hanya menempel pada sesama pasir itu sendiri memudahkan anak membuat berbagai bentuk yang diinginkan sesuai imajinasinya. Selanjutnya menurut Karmakar dkk., (2017) pasir ajaib merupakan butiran mainan hidrofobik yang banyak digunakan dalam pembelajaran sains karena sifat mekanismenya yang tidak intuitif. Ketika butiran pasir ajaib dituangkan ke dalam air, maka secara spontan membentuk gumpalan yang melekat satu dengan yang lainnya.

Dari analisis hasil serta pembahasan penelitian, dapat ditarik kesimpulan bahwa perkembangan kreativitas anak dapat dikembangkan melalui permainan pasir ajaib. Karena dengan permainan pasir ajaib tidak hanya melatih kreativitas dan imajinasi anak dengan menuangkan berbagai ide yang ada dalam pikirannya untuk membuat suatu bentuk, tetapi juga dapat mengembangkan kemampuan motorik halus anak melalui garakan menggenggam, meremas, mengepal, menekan membuat suatu bentuk, melatih sosialisasi anak bermain bersama teman, mengenal bentuk, warna, menyenangkan dan ekspresi anak dapat terlihat ketika anak berhasil menciptakan suatu bentuk.

\section{KESIMPULAN}

Salah satu perkembangan yang mesti dikembangkan ialah kreativitas. Kreativitas tidak hanya menjadikan anak lebih percaya diri dan kreatif tetapi juga terbiasa menggagas pikirannya dan kreatif dalam membuat suatu karya. Kreativitas anak akan lebih berkembang dengan ide yang baru salah satunya menggunakan pasir ajaib. Pasir ajaib ini dapat digunakan anak dalam kegiatan menggambar dan membentuk. Perkembangan kreativitas anak melalui permainan pasir ajaib ini dapat meningkatkan imajinasi anak dalam mengembangkan kreativitas, bisa menuangkan ide-ide yang ada dalam pikiran anak, melatih kepercayaan diri anak, dapat menstimulasi perkembangan anak, menstimulasi kreativitas anak dalam membentuk suatu karya yang baru, dan aman digunakan anak dalam bermain.

\section{UCAPAN TERIMA KASIH}

Penulis mengucapkan terimakasih kepada dosen pembimbing atas bimbingannya, kepada reviewer, editor, tim Aulad: Journal on Early Childhood, dan semua pihak yang telah membantu menelaah artikel ini sehingga artikel ini dapat diterbitkan.

\section{DAFTAR PUSTAKA}

Andreeva, I., Petuhova, O., Vavilova, K., Volkova, T., \& Shalaeva, S. (2018). Development of Children's Creative Abilities While Working With Kinetic Sand. Social Science and Humanities, July, 2-4.

Annisa, Zulkifli, \& Risma, D. (2018). The Effect of Kinetic Sand on Fine Motor Skills of Children Aged 4-5 Years At Tk Riadhussolihin Rambah Subdistrict Rokan Hulu District. Jom Fkip Volume, 5(1), 1-14. 
Asmah, A., \& Mustaji, N. (2014). Pengaruh Pemanfaatan Lingkungan Alam Pasir Sebagai Sumber Belajar Terhadap Kemampuan Sains Dan Motorik Halus Anak Usia Dini. Kwangsan: Jurnal Teknologi Pendidikan, 2(1), 13. https://doi.org/10.31800/jtp.kw.v2n1.p13--36

Azeri, A. R. K., Parvizi, R., Khaleghi, S. J., \& Hosseini, S. B. (2015). Effective Design Principles in Promotion of Children's Creativity in Residential Spaces. Procedia - Social and Behavioral Sciences, 202(December 2014), 31-46. https://doi.org/10.1016/j.sbspro.2015.08.206

Blazhenkova, O., \& Booth, R. W. (2020). Individual Differences in Visualization and Childhood Play Preferences. Heliyon, 6(6), e03953. https://doi.org/10.1016/j.heliyon.2020.e03953

Dunggio, F. (2019). Meningkatkan Kemampuan Motorik Halus Dan Kreativitas Anak Dengan Menggunakan Pendekatan Saintifik Melalui Media Pasir Ajaib Pada Anak Di Kabupaten Pohuwato. Jurnal Pendidikan Glasser, 3(2), 224. https://doi.org/10.32529/glasser.v3i2.295

Fakhriyani, D. V. (2016). Pengembangan Kreativitas Anak Usia Dini. Wacana Didaktika, 4(2), 193-200. https://doi.org/10.31102/wacanadidaktika.4.2.193-200

Hamzah, A. (2020). Metode Penelitian Kepustakaan Library Research Kajian Filosofis, Teoritis, Aplikasi, Proses, dan Hasil Penelitian (Edisi Revisi). Literasi Nusantara.

Hidayati, I. (2020). Pengenalan Bentuk Geometri Melalui Penerapan Media Pasir Kinetik Untuk Anak Usia 2-3 Tahun Di Ppt Mawar 01ar-Rachman Surabaya. Motoric, 4(1), 100-109. https://doi.org/10.31090/m.v4i1.891

Hurlock, E. B. (1978). Perkembangan Anak Jilid 2 (Ke-6). Erlangga.

Karmakar, S., Sane, A., Bhattacharya, S., \& Ghosh, S. (2017). Mechanics of a Granular Skin. Physical Review E, 95(4), 042903. https://doi.org/10.1103/PhysRevE.95.042903

Khamaliyah, A., Fatimah, A., \& Kusumawardani, R. (2019). Pengaruh bermain pasir kinetik terhadap kreativitas anak. Jpp Paud Fkip Untirta, 6, 21-28. https://doi.org/http://dx.doi.org/10.30870/jpppaud.v6i1.7369

Kurniawan, H., Marwany, \& Laely, T. A. (2020). Bermain dan Permainan Anak Usia Dini. PT Remaja Rosdakarya.

Lestari, N. G. A. M. Y. (2020). Penerapan Metode Mind Map Dalam Pengembangan. Pratama Widya: Jurnal Pendidikan Anak Usia DIni, 5(1), 35-42. https://doi.org/http://dx.doi.org/10.25078/pw.v5i1.1357

Lucas, F. M. M. (2017). The Game as an Early Childhood Learning Resource for Intercultural Education. Procedia Social and Behavioral Sciences, 237(June 2016), 908-913. https://doi.org/10.1016/j.sbspro.2017.02.127

Mardiati, \& Hartati, S. (2020). Pengaruh Penggunaan Pasir Kinetik Terhadap Perkembangan Motorik Halus Anak di Taman Kanak-kanak. Jurnal Pendidikan Tambusai, 4, 514-519. https://doi.org/https://doi.org/10.31004/jptam.v4i1.492

Masganti, Khadijah, Nasution, F., Wahyuni, S., Rohani, Nurhayani, Sitorus, A. S., Armayanti, R., \& Lubis, H. Z. (2016). Pengembangan Kreativitas Anak Usia Dini (Teori dan Praktik). Perdana Publishing.

Maulana, I., \& Mayar, F. (2019). Pengembangan Kreativitas Anak Usia Dini di Era Revolusi 4.0. Jurnal Pendidikan Tambusai, 3(3), 1141-1149. https://doi.org/https://doi.org/10.31004/jptam.v3i3.333

Mirzaqon, A. (2018). Studi Kepustakaan Mengenai Landasan Teori Dan Praktik Konseling Expressive Writing Library. Jurnal BK UNESA, 1, 1-8.

Muthiah, Sumardi, \& Rahman, T. (2020). Desain Media Pasir Kinetik untuk Memfasilitasi Kemampuan Permulaan Anak Usia Dini. Jurnal PAUD Agapedia, 4(2), 207-218. https://doi.org/https://doi.org/10.17509/jpa.v4i2.30440

Nurani, Y., Hartati, S., \& Sihadi. (2020). Memacu Kreativitas Melalui Bermain. Bumi Aksara.

Nurhidayah. (2018). Permainan Pasir Kinetik Untuk Mengatasi Permasalahan Ketergantungan Gadget Pada Anak Usia Sekolah Dasar Kinetic Sand Games To Overcome The Dependence Of Gadget Dependence On Children In Elementary School Age. 2(2), 179-185.

Oktariana, R., \& Nufus, H. (2016). Peningkatan Kreativitas Anak Melalui Kegiatan Bermain Pasir pada Anak Kelompok Bermain di PAUD Ar-Rahmah. Jurnal Buah Hati, 3(2), 35-57. https://doi.org/https://doi.org/10.46244/buahhati.v3i2.549

Peleg, R., Katchevich, D., Yayon, M., Mamlok-naaman, R., Dittmar, J., \& Eilks, I. (2015). The magic sand mystery. Science in School, 32, 37-40.

Rachmawati, Y., \& Kurniati, E. (2019). Strategi Pengembangan Kreativitas Pada Anak Usia Taman Kanak-kanak. Kencana.

Ramdhani, A., Ramdhani, M. A., \& Amin, A. S. (2014). Writing a Literature Review Research Paper: A Step-by-step Approach. International Journal of Basics and Applied Sciences, 3(1), 47-56.

Sujiono, Y. N. (2013). Konsep Dasar Pendidikan Anak Usia Dini. PT Indeks.

Susanto, A. (2017). Pendidikan Anak Usia Dini (Konsep dan Teori). Bumi Aksara.

Suyadi, \& Ulfah, M. (2015). Konsep Dasar PAUD. PT Remaja Rosdakarya.

Takahopekang, C. R., Erivia, F., Danjie, K., \& Nafiqoh, H. (2020). Jurnal Ceria (Cerdas Energik Responsif Inovatif Adaptif) Kreativitas Anak Usia Dini Melalui Metode Bermain Pasir Ajaib. Jurnal Ceria (Cerdas Energik Responsif Inovatif Adaptif), 3(2), 181-189. https://doi.org/http://dx.doi.org/10.22460/ceria.v3i2.p\%25p

Umami, R., Sunaringtyas, W., \& Ishariani, L. (2020). Pengaruh Kinetic Play Sand Terhadap Kemampuan Adaptasi Lingkungan Sekolah Pada Anak Preschool. Jurnal Penelitian Keperawatan, 6(2), 86-96. https://doi.org/10.32660/jpk.v6i2.486 
Wahyuni, S., Rahelly, Y., \& Syafdaningsih. (2017). Pengaruh Bermain Media Pasir Terhadap Kreativitas Pada Anak Di Kelompok B Tk Negeri Pembina 2. Tumbuh Kembang: Kajian Teori Dan Pembelajaran PAUD, 4(2), 66-74. https://doi.org/https://doi.org/10.36706/jtk.v4i2.8176

Wulandari, Fitri, Muslihin, H. Y., \& Nur, L. (2020). Penerapan Bermain Konstruksi Magic Sand Untuk Mengembangkan Kemampuan Motorik Halus Anak Usia Dini. JIV-Jurnal Ilmiah Visi, 15(1), $63-72$. https://doi.org/10.21009/JIV.1501.7

Wulandari, Fitrianti. (2018). Pengaruh Bermain Kinetic Sand Terhadap Kreativitas Anak Usia 5-6 Tahun. Jurnal Anak Usia Dini, 3(2), 18-23. https://doi.org/http://dx.doi.org/10.30651/pedagogi.v3i2.1531

Yildirim, A. (2010). Creativity in Early Childhood Education Program. Procedia - Social and Behavioral Sciences, 9 , 1561-1565. https://doi.org/10.1016/j.sbspro.2010.12.365 